\title{
Analysis of ginger drying inside a natural convection indirect solar dryer: An experimental study
}

\author{
S. K. Sansaniwal ${ }^{1 *}$ and M. Kumar ${ }^{2}$ \\ ${ }^{1}$ Thermochemical Conversion Division, \\ Sardar Swaran Singh National Institute of Renewable Energy, \\ Kapurthala-144601, India \\ *Email: sansaniwal@gmail.com \\ Phone: +919996815551; Fax: +91166227602 \\ ${ }^{2}$ Mechanical Engineering Department, \\ Guru Jambheshwar University of Science and Technology, \\ Hisar -125001, India
}

\begin{abstract}
In this paper, a natural convection indirect solar cabinet dryer has been fabricated to study the drying behaviour of ginger rhizomes in terms of its convective heat transfer coefficient and moisture removing rate $(\% \mathrm{db})$. Various experiments were conducted during the months of March and April 2014 at Guru Jambheshwar University of Science and Technology, Hisar $\left(29^{\circ} 5^{\prime} 5^{\prime}\right.$ 'N, $7^{\circ} 45^{\prime} 55^{\prime}$ 'E), India. Experimental data obtained were used to evaluate the Nusselt number constants using linear regression method. Considering these constants, the average value of convective heat transfer coefficient was obtained and observed to decrease with increase in mass of ginger samples and progression of drying days with variation from 0.59 to $5.42 \mathrm{~W} / \mathrm{m}^{2}{ }^{\circ} \mathrm{C}$ for different mass of ginger samples. The moisture removing rate was reported to increase with increase in mass of ginger samples and decreases significantly with the progression of drying days. The average collector efficiency was also observed to vary from 14.97 to $16.14 \%$ under increasing and decreasing trends of solar radiations from morning to noon and noon to evening respectively. Modified page model was reported best for describing the drying behaviour of different mass of ginger samples. The experimental error in terms of percent uncertainty ranged from 29.19 to $46.25 \%$.
\end{abstract}

Keywords: Indirect solar dryer; ginger drying; natural convection drying; convective heat transfer coefficient; moisture removing rate.

\section{INTRODUCTION}

Ginger, an herb in plant habit is obtained from the rhizomes of zinger officinale. It is mainly found in Asia and believed to be a native of South East Asia. The basic ingredients of ginger are oleoresin, starch, protein, mineral matters, fibers, gums, and carbohydrates. Ginger is an important ingredient of the food with high nutritional value and has become a compulsory item in the Indian kitchen. Ginger is not only used to add food palatability but it is also widely used in ayurvedic medicines, bakery products, wine and meat products, toiletry product, etc [1]. Ginger is the most important cash crop of the world. It is cultivated in India, China, Japan, Nigeria, and Indonesia. India is the largest producer of ginger, contributing about $32.75 \%$ of the total world's ginger production with a total production of 517.8 thousand tons by covering a cultivation area of 108.6 thousand 
hectares [2]. About half of the total production of ginger is being consumed as green ginger whereas the remaining $30 \%$ is converted into dry ginger for medicinal purposes and $20 \%$ is used as seed material [3]. Agricultural product drying has a vital role in the preservation and shelf life improvement of the product after harvesting. In developing countries, sun drying is a popular, effective, and economical method for drying of food and herbal products. Open sun drying is a common food preservation technique used to control the moisture content of the agricultural products. Traditionally, herbs like ginger dried in open sun is very much dependent on the availability of sunshine, requires large drying space and long drying time. Also, the drying product is susceptible to contamination because of rain, storm, insects, and other foreign particles. It is also observed that in open sun drying, the external drying parameters such as heat input, moisture contents, temperature, drying air flow rate, etc. cannot be controlled and hence result in undesirable drying rate $[4,5]$. In order to fulfil the quality food product requirement of the growing population, efficient and affordable drying methods should be practiced. Today's world of growing technology has facilitated various types of drying systems which prevent the deterioration of products along with reduced product drying time. But these drying technologies are not economically feasible as they involve high capital investment and energy cost [6].

In the present time of emerging solar energy applications, solar drying is one of the most promising alternatives to open sun drying. It is an eco-friendly and economically viable technology, thus being used in most developing countries [7]. Many eminent researchers have studied the drying characteristics of ginger using various types of solar dryers. According to Mani et al., the convective heat transfer coefficient of ginger in open sun drying conditions under natural convection mode was reported to be $26.25 \mathrm{~W} / \mathrm{m}^{2}$. The drying rate of hybrid dryer was reported to be more than that of open sun drying with overall drying efficiency of $18 \%$ and $13 \%$ under summer and winter climatic conditions respectively [8]. Tray dryer, heat pump dehumidified dryer, and mixed mode solar dryer have been used for ginger drying. The best quality of ginger was observed in heat pump dehumidified dryer and mixed mode solar dryer at $40^{\circ} \mathrm{C}$ and $62.82^{\circ} \mathrm{C}$ respectively, with no pre-treatment of the product. Modified page model was reported to be best suited to describe the drying behaviour of ginger [9]. The drying characteristics of ginger under tray and heat pump assisted dehumidified drying were also incorporated by single and two stages drying, which reduced the drying time by $59.32 \%$ at $40^{\circ} \mathrm{C}$ [10]. Peeled and unpeeled ginger drying under open sun and solar cabinet dryer has been compared and better drying rate was observed in solar drying against open sun drying. The moisture content of the solar dried unpeeled ginger was observed to be $7.0 \%$, unlike that of open sun drying, which could attain only $17.0 \%$ moisture content [11]. A forced convective cabinet dryer was developed for single layer ginger drying at four different drying air temperatures of $45,50,55$, and $60^{\circ} \mathrm{C}$ with an air velocity fixed at $1.3 \mathrm{~m} / \mathrm{s}$. The moisture content of ginger was observed to reduce from 87 to $6 \%$ on wet basis. The accuracy of different drying models was determined by using non-linear regression method [12]. Drying characteristics of ginger rhizomes having a slicing of different lengths varying from 5 to $50 \mathrm{~mm}$ were studied using different drying methods like sun drying, solar tunnel drying, and cabinet tray drying. The moisture content was observed to reduce from 81.3 to $10 \%$ for all drying methods. It was also observed that the drying of whole ginger rhizomes under open sun took maximum time, followed by solar tunnel drying [13]. A photovoltaic powered indirect forced convection solar dryer was developed for drying ginger with maximum collector temperature of 66 and $81^{\circ} \mathrm{C}$ without and with the use of reflector mirror respectively. The product surface temperature was observed to be 63 and 
$65^{\circ} \mathrm{C}$ without and with reflector respectively. The average collector efficiency was reported to increase by $8.04 \%$ with reflector. The drying time was observed to reduce by $66.7 \%$ against open sun drying [14]. Drying kinetics of ginger rhizomes under blanched and non-blanched conditions was presented using hybrid solar dryer and the drying rate dependency on product shape, size, and drying air temperature was observed. Drying air temperature of $70^{\circ} \mathrm{C}$ was reported best for better quality drying of ginger rhizome. Page model was reported best to describe the drying characteristics of ginger rhizome [15]. Thin layer solar drying of ginger was carried out for different mass flow rates of 0.06 and $0.12 \mathrm{~kg} / \mathrm{s}$ with an average temperature of 54 and $44^{\circ} \mathrm{C}$ respectively, for which Page model was reported to be most appropriate to describe the drying behaviour of ginger [7]. A solar drier was designed with evacuated tube collectors for ginger drying at different air mass flow rates varying from 4 to $5 \mathrm{~m} / \mathrm{s}$ and reduced the moisture content of the product from 85.62 to $0.92 \%$. The drier efficiency was reported to vary from 31 to $40.4 \%$ for different air mass flow rates. Overall, the dryer was suggested to be better than other dryers in terms of quality and drying rate [3]. Drying characteristics of ginger using a mixed mode solar cabinet dryer were investigated by reducing its moisture from 621.50 to $12.19 \%$. Solar cabinet dryer was observed to be better for ginger drying in the aspects of quality, drying time, and power requirement as compared to open sun drying. Page model was reported to be most suitable to describe the drying characteristics of ginger [16].

In the present study, an indirect natural convection solar dryer has been fabricated to study the drying kinetics of ginger in the meteorological conditions of Hisar $\left(29^{\circ} 5^{\prime} 5^{\prime} \mathrm{N}, 75^{\circ} 45^{\prime} 55^{\prime} \mathrm{E}\right)$, India. Solar flat plate collector efficiency has also been evaluated for the given drying time interval.

\section{Experimental Setup}

\section{MATERIAL AND METHODS}

Different views of natural convection indirect solar dryer fabricated in the meteorological conditions of Hisar $\left(29^{\circ} 5^{\prime} 5^{\prime}\right.$ ' $\mathrm{N}, 7^{\circ} 45^{\prime} 55^{\prime}$ 'E), India, are shown in Figure 1. It comprised of two main elements, namely solar collector and drying chamber. Solar collector $(1.3 \mathrm{~m}$ $\times 1 \mathrm{~m}$ ) having black coated galvanized iron sheet with thermocol insulation was used for air heating. A transparent glass sheet of thickness $8 \mathrm{~mm}$ was located over the collector to achieve the desired glazing effects. The drying chamber $(0.41 \mathrm{~m} \times 0.45 \mathrm{~m} \times 0.53 \mathrm{~m})$ was thermally insulated with glass wool to minimize the heat losses. The heated air in the collector was allowed to flow in the drying chamber through PVC pipe. Accurately weighed ginger samples of initial moisture content $78 \%$ were evenly distributed on rectangular shaped wire mesh trays $(0.11 \mathrm{~m} \times 0.20 \mathrm{~m}, 0.23 \mathrm{~m} \times 0.20 \mathrm{~m})$. The warmed air evaporated the moisture of different mass of ginger samples. After the predetermined time interval of 1 hour, weight reduction of product was noted by using an electronic weighing balance (model TJ-6000, capacity $6 \mathrm{~kg}$, least count of $0.1 \mathrm{gm}$ ). A digital hygrometer (model HT-315) was located just above the product surface to monitor the relative humidity and product surrounding temperature. The temperature of air was measured by thermocouples (PT-100 with accuracy $\pm 0.1^{\circ} \mathrm{C}$ ) at different locations of solar collector ( $T_{s}$ ) and drying chamber as shown in Figure 1. The velocity of fresh air at collector inlet was measured by digital anemometer (model AM-4201, least count $0.1 \mathrm{~m} / \mathrm{s}$ ). A digital solar power meter (model WACO-206, least readability $\pm 10 \mathrm{~W} / \mathrm{m}^{2}$ ) was used to collect the solar radiation data of drying days. The schematic and pictorial view of natural convection indirect solar dryer is shown in Figure 1. 


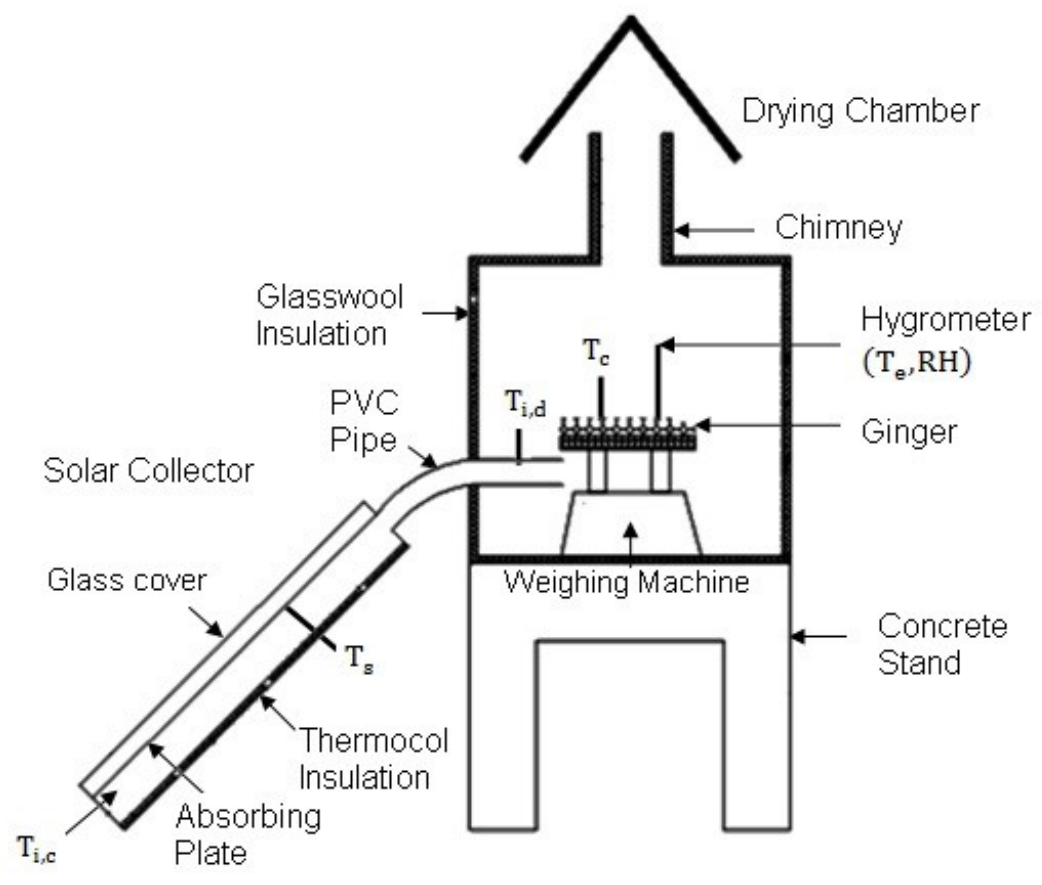

(a)

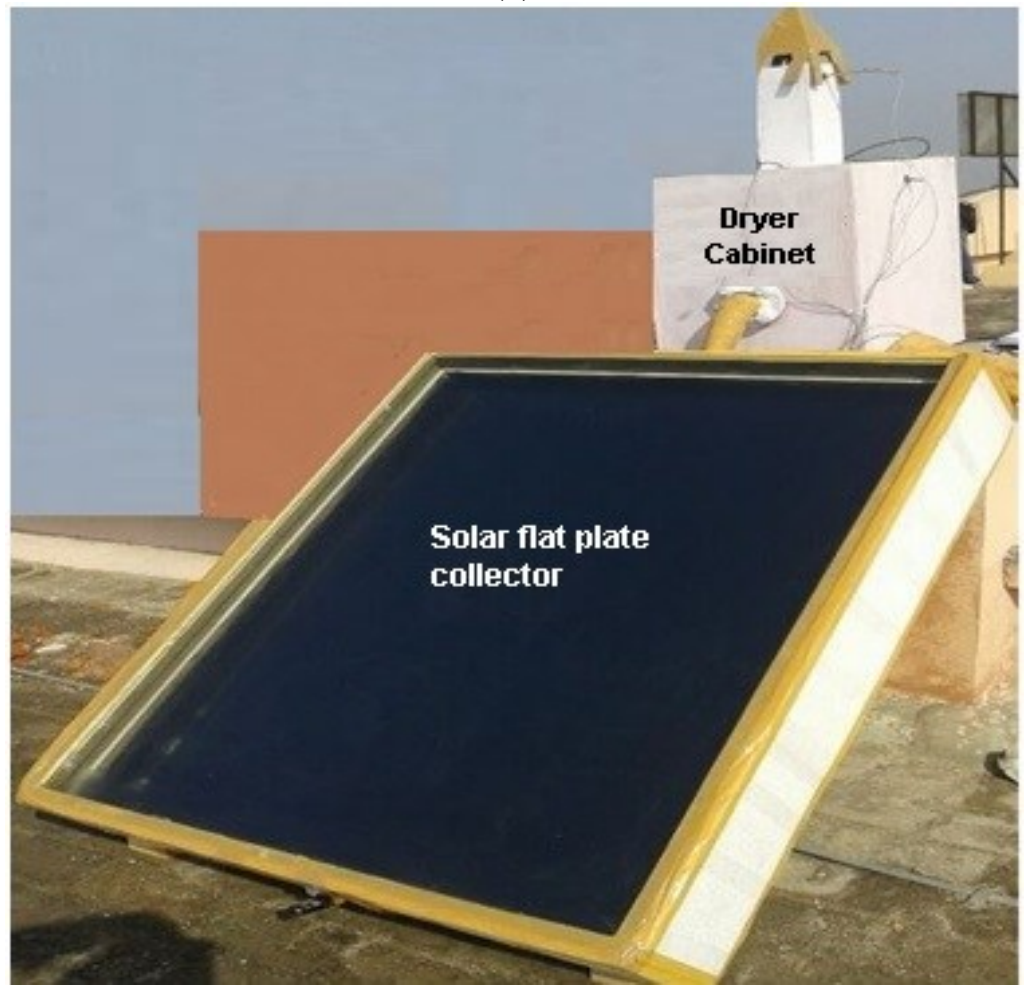

(b)

Figure 1. Experimental setup (a) schematic view; (b) pictorial view.

\section{Sample Preparation}

Fresh ginger was purchased from local market of Hisar, India and washed thoroughly to remove the surface dust. The clean ginger was hand peeled by knife and shaped cylindrically with a diameter of $1.7 \mathrm{~cm}$ and length of $3 \mathrm{~cm}$. The samples were 
accommodated in a rectangular-shaped wire mesh tray placed on the weighing balance. The initial moisture content of fresh ginger was determined by hot air oven drying method [17].

\section{Experimental Procedure}

Experimental observations were recorded between 9:00 am to 6:00 pm in the month of March and April 2014 at Guru Jambheshwar University of Science and Technology, Hisar. Two different sizes of rectangular-shaped wire mesh trays were used to accommodate different mass of ginger samples. These trays were kept on the digital electronic balance machine to determine the moisture content removal for each drying hour. A digital humidity meter (Model HT-315) was kept just above the ginger samples surface facing its probe towards the ginger sample surface. Every time, it was started 1 minute before recording the observations. Temperature was measured by using calibrated thermocouples at different locations, namely dryer inlet temperature, product surface temperature, chimney inlet and outlet temperature and absorbing plate temperature of the collector. A digital anemometer (Model AM-4201) having a readability of $0.1 \mathrm{~m} / \mathrm{s}$ was used to measure the air flow at collector inlet air passage. Solar radiation data of drying days was collected by digital solar power meter (model WACO-206). Experimental observations were recorded at every 1 hour time interval. Measurement was discontinued when the constant weight of samples was achieved. The difference in weight directly gave the quantity of water content evaporated during any time interval. Wet and dried ginger samples are shown in Figure 2.

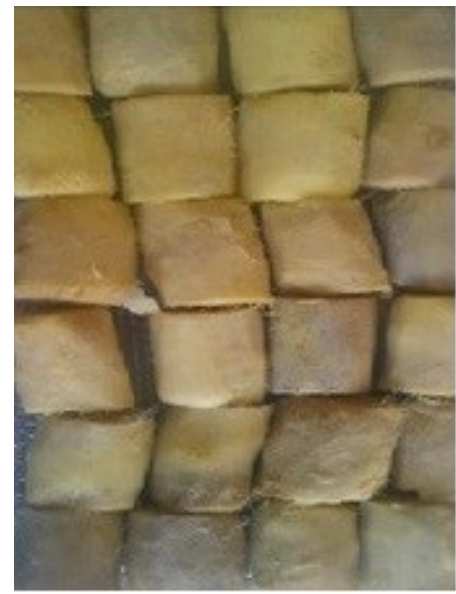

(a)

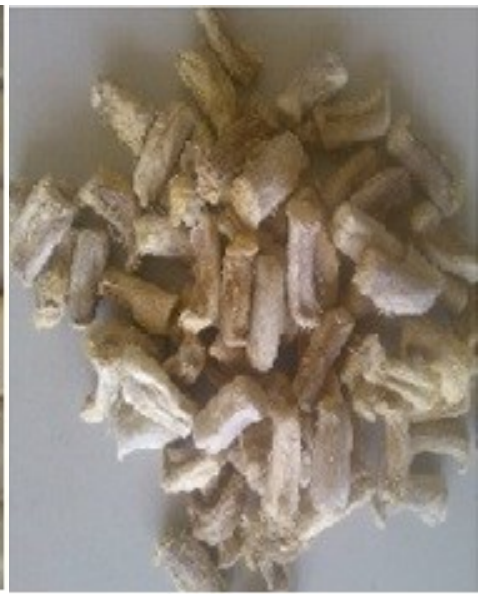

(b)

Figure 2. Ginger samples (a) before drying; (b) after drying.

The data obtained from the measurements of ginger weight were used for drying kinetics analysis of ginger in terms of moisture removing rate. The moisture removing rate was expressed on a dry basis. The experimental data were fitted to the thin layer drying models by using non-linear regression analysis as shown in Table 1.

Moisture removing rate on \% dry basis can be calculated using Eq. (1):

$$
M_{\text {initial }}=\frac{W_{w}-W_{d}}{W_{d}} \times 100
$$


where $M_{\text {initial }}$ is the initial moisture removing rate (\%, dry basis), $W_{w}$ is the weight of wet ginger $(\mathrm{g})$, and $W_{d}$ is the weight of dry ginger $(\mathrm{g})$.

Table 1. Thin layer drying models.

\begin{tabular}{cccc}
\hline Serial No. & Model Name & Model & Reference \\
\hline 1 & Page & $M R=\exp \left(-k t^{n}\right)$ & {$[18]$} \\
2 & Modified Page & $M R=\exp \left[(-k t)^{n}\right]$ & {$[19]$} \\
3 & Henderson \& Pabis & $M R=a \exp (-k t)$ & {$[20]$} \\
4 & Wang \& Singh & $M R=1+a t+k t^{2}$ & {$[21]$} \\
\hline
\end{tabular}

The moisture ratio of ginger during the drying can be obtained using Eq. (2):

$$
M R=\frac{M-M_{e}}{M_{o}-M_{e}}
$$

where $M$ is the moisture content at any drying time (\%, dry basis), $M_{o}$ is the initial moisture content ( $\%$, dry basis), and $M_{e}$ is the equilibrium moisture content $(\%$, dry basis).

From the literature, it is observed that the ginger should be dried from its average initial moisture content of $89 \%$ to the final moisture content of $8 \%$ [7]. The coefficient of determination $\left(R^{2}\right)$, reduced chi square $\left(\chi^{2}\right)$, and root mean square error $(R M S E)$ were considered to be the primary criteria to determine the suitability of best thin layer drying model as given in Eq. (3) and Eq. (4):

$$
\begin{gathered}
\chi^{2}=\frac{\sum_{i=1}^{N}\left(M R_{\text {exp }, i}-M R_{p r e, i}\right)^{2}}{N-n} \\
R M S E=\frac{1}{N}\left[\frac{\sum_{i=1}^{N}\left(M R_{\text {exp }, i}-M R_{p r e, i}\right)^{2}}{N}\right]^{1 / 2}
\end{gathered}
$$

where $M_{\text {exp }, i}$ is experimental moisture ratio, $M_{\text {pre }, i}$ is predicated moisture ratio, $N$ is the number of observations, and $n$ is the number of drying model constant.

The model suitability was determined by considering the higher value of coefficient of determination and least value of chi square and root mean square error [16]. Statistical parameters obtained from selected thin layer drying models are given in Table 2. From Table 2, it can be observed that the modified page model has the highest value of coefficient of determination $\left(R^{2}\right)$ and corresponding least value of chi square $\left(\chi^{2}\right)$ and 
root mean square error (RMSE) among the four models used. So it has been concluded that the modified page model is best suited for describing the drying behaviour of different ginger mass samples.

Table 2. Statistical parameters obtained from selected thin layer drying models for solar cabinet drying of ginger.

\begin{tabular}{ccccccc}
\hline Model Name & \multicolumn{2}{c}{ Number of ginger samples (78) } & \multicolumn{3}{c}{ Number of ginger samples (48) } \\
\cline { 2 - 7 } & $R^{2}$ & $R M S E$ & $\chi^{2}$ & $R^{2}$ & $R M S E$ & $\chi^{2}$ \\
Page & 0.9434 & 0.071 & 0.5021 & 0.9070 & 0.101 & 0.9459 \\
Modified Page & 0.9973 & 0.038 & 0.0169 & 0.9797 & 0.028 & 0.1388 \\
Henderson \& Pabis & 0.7613 & 0.238 & 4.9373 & 0.7361 & 0.263 & 5.4866 \\
Wang \& Singh & 0.8731 & 0.120 & 1.8432 & 0.8458 & 0.154 & 2.2438 \\
\hline
\end{tabular}

\section{THEORETICAL CONSIDERATIONS}

\section{Thermal Modelling}

The convective heat transfer coefficient for evaporation was determined using the following relations [22]:

$$
N u=\frac{h_{c} X}{K_{v}}=C(G r \operatorname{Pr})^{n}
$$

where $N u$ is the Nusselt number, Re is the Reynolds Number, $G r$ is the Grashof Number, Pr is the Prandtl Number, $h_{c}$ is convective heat transfer coefficient $\left(\mathrm{W} / \mathrm{m}^{2 \circ} \mathrm{C}\right), X$ is characteristic length $(\mathrm{m}), K_{v}$ is the thermal conductivity $\left(\mathrm{W} / \mathrm{m}^{\circ} \mathrm{C}\right)$, while $C$ and $n$ are Constant.

The rate of heat utilized to evaporate moisture is given as

$$
Q_{e}=0.016 h_{c}\left[P\left(T_{c}\right)-\lambda P\left(T_{e}\right)\right]
$$

On substituting $h_{c}$ from Eq. (5), Eq. (6) becomes

$$
Q_{e}=0.016 \frac{K_{v}}{X} C(G r \operatorname{Pr})^{n}\left[P\left(T_{c}\right)-\lambda P\left(T_{e}\right)\right]
$$

where $T_{c}$ is the product temperature $\left({ }^{\circ} \mathrm{C}\right), T_{e}$ is the product surrounding temperature $\left({ }^{\circ} \mathrm{C}\right)$, and $P(T)$ is the vapour pressure at temperature $\mathrm{T}\left(\mathrm{N} / \mathrm{m}^{2}\right)$.

The moisture evaporated is determined by dividing Eq. (7) by latent heat of vaporization $(\lambda)$ and multiplying the area of tray $\left(A_{t}\right)$ and drying time interval $(t)$.

$$
m_{e v}=\frac{Q_{e}}{\lambda}\left(A_{t} t\right)=0.016 \frac{K_{v}}{X} C(G r \operatorname{Pr})^{n}\left[P\left(T_{c}\right)-\lambda P\left(T_{e}\right)\right]\left(A_{t} t\right)
$$


Let

$$
0.016 \frac{K_{v}}{X \lambda}\left[P\left(T_{c}\right)-\lambda P\left(T_{e}\right)\right]\left(A_{t} t\right)=Z \quad \frac{m_{e v}}{Z}=C(G r \operatorname{Pr})^{n}
$$

Taking logarithm of both sides of Eq. (9),

$$
\ln \left[\frac{m_{e v}}{Z}\right]=\ln C+n \ln (G r \operatorname{Pr})
$$

This is in the form of a linear equation,

$$
y=m x+C
$$

Where

$$
\begin{gathered}
y=\ln \left[\frac{m_{e v}}{Z}\right], m=n, \\
x=\ln (G r \operatorname{Pr}), \text { and } c=\ln C
\end{gathered}
$$

Values of ' $m$ ' and ' $C$ ' in Eq. (11) are obtained using the simple linear regression method with the following formulae:

$$
m=\frac{N \sum X_{0} Y-\sum X_{0} \sum Y}{N \sum X_{0}^{2}-\left(\sum X_{0}\right)^{2}}
$$

And

$$
c=\frac{\sum X_{0}^{2} \sum Y-\sum X_{0} \sum X_{0} Y}{N \sum X_{0}^{2}-\left(\sum X_{0}\right)^{2}}
$$

Hence, the constant ' $C$ ' and exponent ' $n$ ' can be obtained from the above equations.

\section{Thermal Properties of Air}

The physical properties of humid air can be determined using the following expressions [23]:

$$
\begin{gathered}
C_{v}=999.2+0.143 T_{i}+1.101 \times 10^{-4} T_{i}^{2}-6.7581 \times 10^{-8} T_{i}^{3} \\
K_{v}=0.0244+0.7673 \times 10^{-4} T_{i} \\
K_{v}=\frac{353.44}{T_{i}+273.15} \\
\mu_{v}=1.718 \times 10^{-5}+4.620 \times 10^{-8} T_{i}
\end{gathered}
$$

where, $\mu_{v}$ is the dynamic viscosity of air $(\mathrm{kg} / \mathrm{m} . \mathrm{s})$

$$
P(T)=\exp \left[25.317-\frac{5144}{T_{i}+273.15}\right]
$$


where $P(T)$ is the vapour pressure at temperature $\mathrm{T}\left(\mathrm{N} / \mathrm{m}^{2}\right)$ and $T_{i}=\left(T_{c}+T_{e}\right) / 2$

\section{Solar Flat Plate Collector Efficiency}

Total heat at solar flat plate collector outlet can be calculated using Eq. (19) [24]:

$$
Q_{o}=V_{o} \times A_{o, c} \times \rho_{v} \times\left(T_{o, c}-T_{i, c}\right) \times c_{v}
$$

where $Q_{o}$ is the total heat output $(\mathrm{J} / \mathrm{sec}), V_{o}$ is the average air velocity at collector outlet $(\mathrm{m} / \mathrm{s}), A_{o, c}$ is the area of collector outlet $\left(\mathrm{m}^{2}\right), \rho_{v}$ is the density of air $\left(\mathrm{kg} / \mathrm{m}^{3}\right), T_{o, c}$ is the temperature at collector outlet $\left({ }^{\circ} \mathrm{C}\right), T_{i, c}$ is temperature at collector inlet $\left({ }^{\circ} \mathrm{C}\right)$, and $c_{v}$ is the specific heat of air $\left(\mathrm{J} / \mathrm{kg}^{\circ} \mathrm{C}\right)$.

Total amount of heat received by the solar flat plate collector is given by Eq. (20):

$$
Q_{i}=I \times A_{c}
$$

where $Q_{i}$ is the heat input $(\mathrm{J} / \mathrm{sec}), I$ is the solar irradiation $\left(\mathrm{W} / \mathrm{m}^{2}\right)$, and $A_{c}$ is the apparent area of collector.

Efficiency of solar flat plate collector can be determined by dividing Eq. (19) and Eq. (20):

$$
\eta_{c}=\frac{Q_{o}}{Q_{i}}
$$

\section{Experimental Errors}

The experimental errors were evaluated in terms of percentage of uncertainty using Eq. (21) for the mass of moisture evaporated during drying of ginger samples [25].

$$
\% \text { uncertainity }=(\mathrm{U} / \text { mean of the total observations }) \times 100
$$

Where

$$
U=\frac{\sqrt{\delta_{1}^{2}+\delta_{2}^{2}+\ldots \ldots .+\delta_{N}^{2}}}{N_{o}}
$$

Where $\delta$ is the standard deviation and $N_{o}$ is the number of sets.

\section{RESULTS AND DISCUSSION}

The hand-peeled cylindrically shaped (diameter $1.7 \mathrm{~cm}$, length $3 \mathrm{~cm}$ ) different masses of ginger samples were dried under natural convection mode. Drying tests of different mass, i.e. 78 and 48 no. of ginger samples were run by using two different rectangular trays. 
Collector efficiency, moisture removing rate (\%, dry basis), and convective heat transfer coefficients for 78 and 48 no. of ginger samples were evaluated as given in Table 3.

Table 3. Experimental data during natural convection indirect solar drying of different no. of ginger samples.

\begin{tabular}{|c|c|c|c|c|c|c|c|c|c|c|}
\hline $\begin{array}{l}\text { Time } \\
\text { (Hour) }\end{array}$ & $\begin{array}{c}T_{s} \\
\left({ }^{\circ} \mathrm{C}\right)\end{array}$ & $\begin{array}{l}T_{i, c} \\
\left({ }^{\circ} \mathrm{C}\right)\end{array}$ & $\begin{array}{l}T_{o, c} \\
\left({ }^{\circ} \mathrm{C}\right)\end{array}$ & $\begin{array}{c}I \\
\left(\mathrm{~W} / \mathrm{m}^{2}\right)\end{array}$ & $\begin{array}{c}\eta_{c} \\
(\%)\end{array}$ & $\begin{array}{c}T_{c} \\
\left({ }^{\circ} \mathrm{C}\right)\end{array}$ & $\begin{array}{c}T_{e} \\
\left({ }^{\circ} \mathrm{C}\right)\end{array}$ & $\begin{array}{l}\text { Mass } \\
(\mathrm{g})\end{array}$ & $\begin{array}{c}M_{e v p} \\
(\mathrm{~g})\end{array}$ & $\begin{array}{c}h_{c} \\
\left(\mathrm{~W} / \mathrm{m}^{2 \circ} \mathrm{C}\right)\end{array}$ \\
\hline \multicolumn{11}{|c|}{78 no. of ginger samples on the first day of drying $(18 / 03 / 2014)$} \\
\hline 09:00 & 48.2 & 25.8 & 43.7 & 434 & - & 26.5 & 26.5 & 516.3 & - & - \\
\hline $10: 00$ & 59.6 & 31.2 & 57.4 & 506 & 16.19 & 35.0 & 34.3 & 507.7 & 8.6 & 4.71 \\
\hline $11: 00$ & 65.8 & 32.8 & 64.3 & 570 & 16.98 & 38.5 & 38.0 & 490.7 & 17.0 & 4.82 \\
\hline $12: 00$ & 70.1 & 34.0 & 68.8 & 603 & 17.52 & 40.9 & 40.4 & 464.6 & 26.1 & 4.88 \\
\hline $13: 00$ & 69.9 & 36.0 & 69.8 & 612 & 16.77 & 42.3 & 41.8 & 437.2 & 27.4 & 4.89 \\
\hline $14: 00$ & 69.2 & 36.1 & 68.2 & 590 & 16.56 & 42.0 & 41.9 & 412.2 & 25.0 & 4.91 \\
\hline $15: 00$ & 61.1 & 35.6 & 62.7 & 502 & 16.81 & 41.0 & 40.8 & 389.2 & 23.0 & 4.78 \\
\hline $16: 00$ & 53.2 & 33.2 & 54.6 & 430 & 15.85 & 38.3 & 38.1 & 367.0 & 22.2 & 4.62 \\
\hline $17: 00$ & 42.7 & 32.4 & 43.3 & 230 & 15.57 & 33.8 & 33.4 & 351.0 & 16.0 & 4.34 \\
\hline \multicolumn{11}{|c|}{78 no. of ginger samples on the second day of drying $(19 / 03 / 2014)$} \\
\hline 09:00 & 34.4 & 23.2 & 29.1 & 401 & - & 22.5 & 21.9 & 355.5 & - & - \\
\hline $10: 00$ & 52.8 & 28.6 & 49.0 & 445 & 14.61 & 30.5 & 29.5 & 337.4 & 18.1 & 2.89 \\
\hline $11: 00$ & 62.3 & 30.7 & 60.6 & 520 & 17.84 & 36.6 & 35.7 & 323.7 & 13.7 & 3.03 \\
\hline $12: 00$ & 69.5 & 33.2 & 67.1 & 601 & 17.15 & 39.8 & 38.9 & 307.8 & 15.9 & 3.09 \\
\hline $13: 00$ & 71.7 & 35.2 & 69.0 & 620 & 16.47 & 41.8 & 40.9 & 293.4 & 14.4 & 3.12 \\
\hline $14: 00$ & 70.5 & 36.1 & 68.6 & 575 & 17.14 & 42.2 & 41.6 & 277.5 & 15.9 & 3.06 \\
\hline $15: 00$ & 64.6 & 35.5 & 64.7 & 535 & 16.82 & 41.9 & 41.3 & 263.9 & 13.6 & 2.98 \\
\hline $16: 00$ & 57.0 & 33.3 & 57.0 & 440 & 16.96 & 39.1 & 38.6 & 252.7 & 11.2 & 2.86 \\
\hline $17: 00$ & 46.4 & 32.7 & 45.8 & 257 & 16.56 & 35.4 & 34.9 & 244.6 & 8.1 & 2.65 \\
\hline $18: 00$ & 35.0 & 31.0 & 34.0 & 62 & 16.27 & 30.9 & 30.0 & 234.9 & 9.7 & 2.40 \\
\hline \multicolumn{11}{|c|}{78 no. of ginger samples on the third day of drying $(20 / 03 / 2014)$} \\
\hline 09:00 & 36.4 & 24.0 & 32.3 & 412 & - & 24.1 & 23.9 & 236.4 & - & - \\
\hline $10: 00$ & 49.8 & 28.5 & 46.6 & 442 & 13.17 & 31.5 & 30.5 & 225.0 & 11.4 & 1.78 \\
\hline $11: 00$ & 56.9 & 32.4 & 53.4 & 501 & 13.20 & 36.5 & 35.2 & 214.5 & 10.5 & 1.85 \\
\hline $12: 00$ & 77.3 & 34.0 & 69.9 & 690 & 15.49 & 43.4 & 42.1 & 202.8 & 11.7 & 1.89 \\
\hline $13: 00$ & 70.2 & 33.2 & 64.9 & 620 & 15.52 & 44.8 & 43.2 & 190.9 & 11.9 & 1.91 \\
\hline $14: 00$ & 68.2 & 36.1 & 61.4 & 430 & 17.95 & 42.2 & 40.9 & 183.7 & 7.2 & 1.87 \\
\hline $15: 00$ & 70.6 & 38.0 & 66.7 & 555 & 15.67 & 46.2 & 44.7 & 176.1 & 7.6 & 1.83 \\
\hline $16: 00$ & 67.4 & 37.2 & 62.6 & 490 & 15.85 & 45.5 & 44.2 & 169.3 & 6.8 & 1.76 \\
\hline $17: 00$ & 52.3 & 36.6 & 50.1 & 280 & 15.39 & 40.3 & 39.2 & 164.8 & 4.5 & 1.65 \\
\hline $18: 00$ & 36.1 & 33.2 & 35.8 & 59 & 14.77 & 32.6 & 31.5 & 161.4 & 3.4 & 1.51 \\
\hline \multicolumn{11}{|c|}{48 no. of ginger samples on the first day of drying $(02 / 04 / 2014)$} \\
\hline 09:00 & 36.4 & 23.6 & 30.8 & 401 & - & 24.9 & 25.34 & 309.2 & - & - \\
\hline $10: 00$ & 51.9 & 26.7 & 49.3 & 497 & 11.19 & 31.95 & 31.63 & 300.2 & 9.0 & 5.54 \\
\hline 11:00 & 63.2 & 31.6 & 57.1 & 545 & 13.51 & 34.65 & 35.84 & 286.1 & 14.1 & 5.65 \\
\hline $12: 00$ & 68.3 & 32.8 & 65.7 & 580 & 15.99 & 40.5 & 42.31 & 271.1 & 15.0 & 4.37 \\
\hline $13: 00$ & 71.9 & 34.8 & 68.2 & 603 & 15.68 & 42.6 & 44.31 & 253.9 & 17.2 & 5.63 \\
\hline
\end{tabular}


Table 3. Continue

\begin{tabular}{|c|c|c|c|c|c|c|c|c|c|c|}
\hline $\begin{array}{l}\text { Time } \\
\text { (Hour) }\end{array}$ & $\begin{array}{c}T_{s} \\
\left({ }^{\circ} \mathrm{C}\right)\end{array}$ & $\begin{array}{l}T_{i, c} \\
\left({ }^{\circ} \mathrm{C}\right)\end{array}$ & $\begin{array}{l}T_{o, c} \\
\left({ }^{\circ} \mathrm{C}\right)\end{array}$ & $\begin{array}{c}I \\
\left(\mathrm{~W} / \mathrm{m}^{2}\right)\end{array}$ & $\begin{array}{c}\eta_{c} \\
(\%)\end{array}$ & $\begin{array}{c}T_{c} \\
\left({ }^{\circ} \mathrm{C}\right)\end{array}$ & $\begin{array}{c}T_{e} \\
\left({ }^{\circ} \mathrm{C}\right)\end{array}$ & $\begin{array}{c}\text { Mass } \\
(\mathrm{g})\end{array}$ & $\begin{array}{c}M_{e v p} \\
(\mathrm{~g})\end{array}$ & $\begin{array}{c}h_{c} \\
\left(\mathrm{~W} / \mathrm{m}^{2 \circ} \mathrm{C}\right)\end{array}$ \\
\hline $14: 00$ & 72.0 & 35.7 & 67.9 & 588 & 15.77 & 43.35 & 45.16 & 238.5 & 15.4 & 5.64 \\
\hline $15: 00$ & 69.3 & 36.3 & 65.5 & 530 & 15.33 & 43.7 & 45.52 & 221.1 & 17.4 & 5.88 \\
\hline $16: 00$ & 61.5 & 35.6 & 59.1 & 470 & 14.55 & 42.25 & 43.90 & 205.1 & 16.0 & 5.85 \\
\hline $17: 00$ & 49.1 & 33.1 & 48.6 & 280 & 13.58 & 37.85 & 39.21 & 193.3 & 11.8 & 5.28 \\
\hline $18: 00$ & 41.0 & 31.5 & 38.8 & 65 & 13.12 & 34.70 & 35.52 & 185.4 & 7.9 & 4.95 \\
\hline \multicolumn{11}{|c|}{48 no. of ginger samples on the second day of drying $(03 / 04 / 2014)$} \\
\hline 09:00 & 37.6 & 28.1 & 34.7 & 413 & - & 27.2 & 27.91 & 192.6 & - & - \\
\hline $10: 00$ & 55.0 & 31.1 & 52.8 & 502 & 13.69 & 33.95 & 34.13 & 177.6 & 15.0 & 3.53 \\
\hline $11: 00$ & 68.3 & 33.1 & 65.0 & 590 & 16.49 & 39.55 & 40.50 & 166.8 & 10.8 & 3.62 \\
\hline $12: 00$ & 74.9 & 38.4 & 71.0 & 602 & 16.22 & 43.2 & 43.85 & 154.0 & 12.8 & 3.61 \\
\hline $13: 00$ & 72.6 & 38.8 & 72.0 & 590 & 16.96 & 45.1 & 45.30 & 136.5 & 17.5 & 3.49 \\
\hline $14: 00$ & 70.6 & 39.2 & 70.9 & 552 & 17.41 & 46.15 & 45.88 & 122.8 & 13.7 & 3.37 \\
\hline $15: 00$ & 64.3 & 38.5 & 66.1 & 490 & 17.37 & 45.55 & 45.11 & 109.0 & 13.8 & 3.21 \\
\hline $16: 00$ & 57.5 & 37.5 & 58.4 & 401 & 16.39 & 42.8 & 42.49 & 100.6 & 8.4 & 3.09 \\
\hline $17: 00$ & 47.4 & 35.2 & 49.0 & 299 & 14.95 & 39.6 & 39.29 & 95.8 & 4.8 & 2.91 \\
\hline $18: 00$ & 37.5 & 34.7 & 37.4 & 68 & 13.25 & 34.7 & 34.65 & 92.5 & 3.3 & 2.76 \\
\hline \multicolumn{11}{|c|}{48 no. of ginger samples on the third day of drying $(04 / 04 / 2014)$} \\
\hline 09:00 & 37.3 & 28.0 & 33.4 & 405 & - & 27.2 & 27.30 & 100.1 & - & - \\
\hline $10: 00$ & 51.2 & 31.4 & 49.8 & 498 & 11.83 & 34.5 & 34.27 & 94.6 & 5.5 & 0.63 \\
\hline $11: 00$ & 56.7 & 32.5 & 58.8 & 520 & 15.94 & 40.7 & 39.98 & 87.6 & 7.0 & 0.63 \\
\hline $12: 00$ & 66.5 & 36.5 & 67.5 & 580 & 16.39 & 45.5 & 44.54 & 81.3 & 6.3 & 0.63 \\
\hline $13: 00$ & 73.2 & 39.0 & 72.2 & 610 & 16.38 & 50.1 & 48.03 & 77.7 & 3.6 & 0.59 \\
\hline $14: 00$ & 59.3 & 37.4 & 58.3 & 515 & 12.70 & 45.2 & 44.21 & 73.2 & 4.5 & 0.58 \\
\hline $15: 00$ & 65.1 & 38.8 & 64.1 & 501 & 15.54 & 47.3 & 46.20 & 72.1 & 1.1 & 0.59 \\
\hline $16: 00$ & 59.8 & 38.0 & 60.2 & 445 & 15.59 & 46.5 & 45.48 & 71.1 & 1.0 & 0.58 \\
\hline $17: 00$ & 49.9 & 37.3 & 50.2 & 293 & 14.15 & 42.5 & 41.61 & 70.5 & 0.6 & 0.55 \\
\hline 18:00 & 39.3 & 36.8 & 39.3 & 63 & 13.17 & 36.3 & 36.7 & 70.2 & 0.3 & 0.61 \\
\hline
\end{tabular}

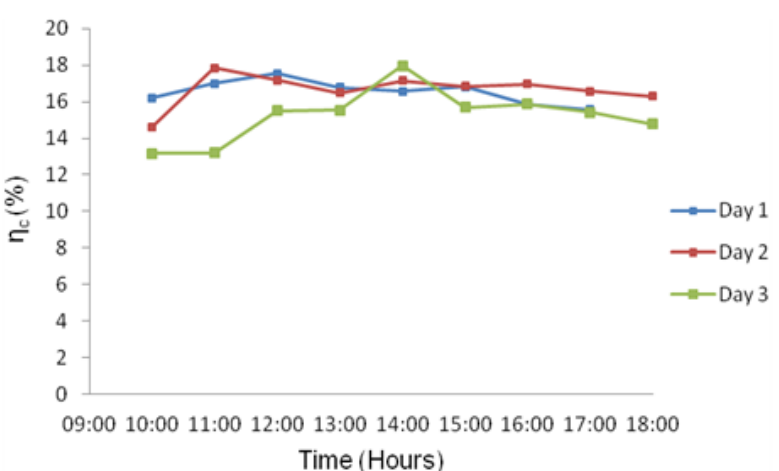

(a)

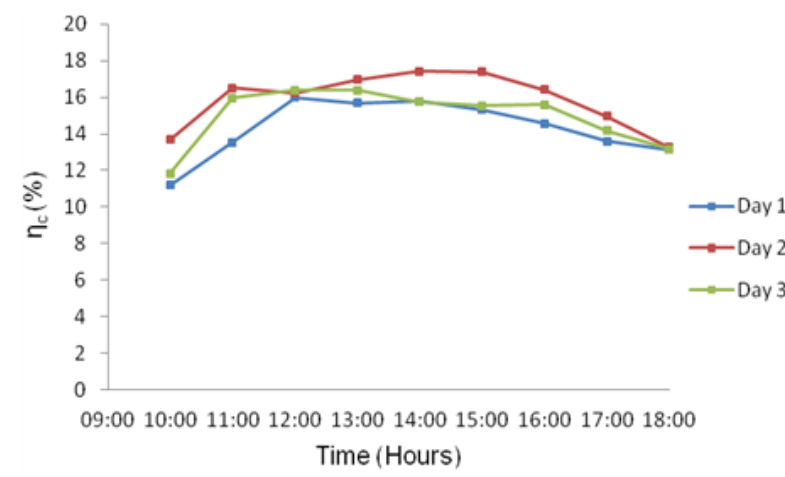

(b)

Figure 3. Variations in collector efficiency with respect to time (a) for 78 no. of ginger samples (b) for 48 no. of ginger samples 
The data given in Table 3 were used to determine the moisture removing rate, drying rate, and convective heat transfer coefficients at drying time of 1 hour interval under natural convection indirect solar drying for first, second, and third day of drying of 78 and 48 numbers of ginger samples as shown in Figure 3. It has been observed that the collector efficiency increases from morning to noon and decreases from noon to evening due to increasing and decreasing trend of solar radiation in a day. The maximum collector efficiency was reported between 12:00 to 14:00 as solar radiation intensity was observed higher during the same time interval. So, the collector efficiency is observed to be a strong function of solar radiation data [26]. In ginger drying, the moisture available with the ginger is present in two forms, namely free moisture and bound moisture. Free moisture is present in the outer resins of the ginger, which can be easily evaporated using suitable amount of heated air where the bound moisture is present in ginger internal cells under capillary action, which takes time for its evaporation and leads to higher drying time.



(a)

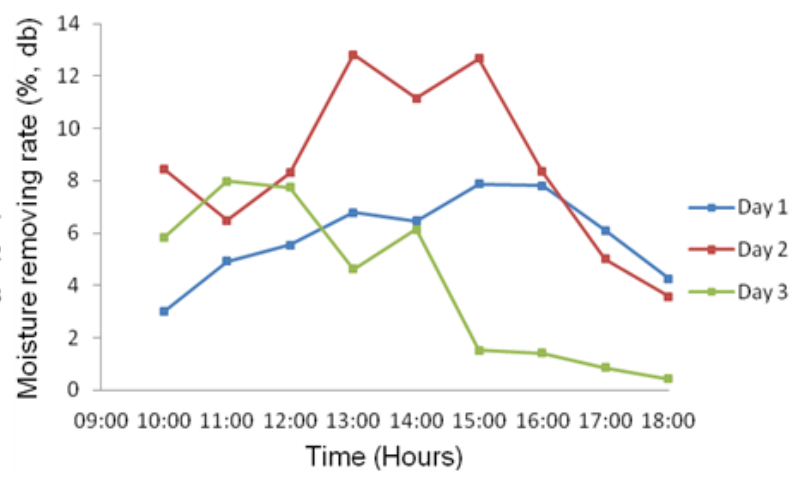

(b)

Figure 4. Variations in moisture removing rate (\%, dry basis) with respect to time (a) for 78 no. of ginger samples (b) for 48 no. of ginger samples

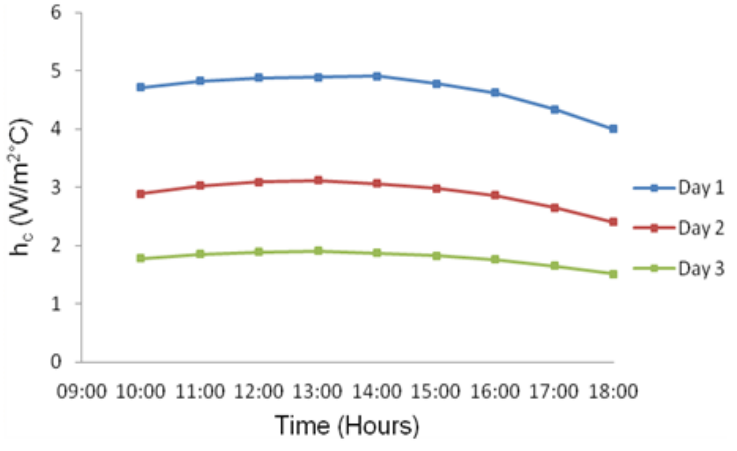

(a)

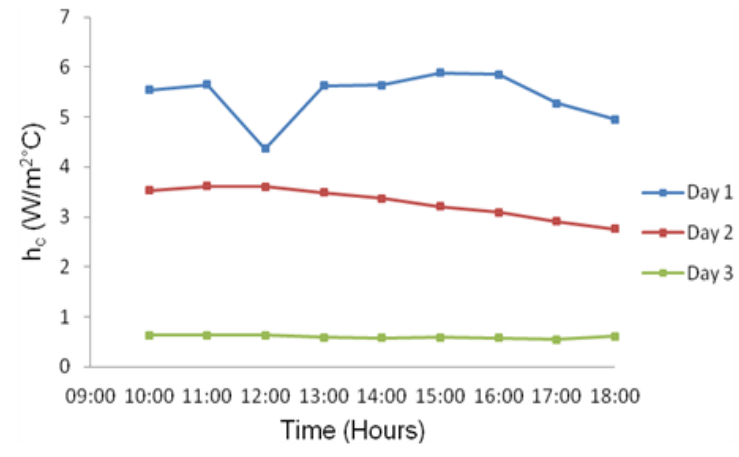

(b)

Figure 5. Variations in convective heat transfer coefficients with respect to time (a) for 78 no. of ginger samples (b) for 48 no. of ginger samples.

In Figure 4, the moisture removing rate is observed to be dependent on the total moisture present in the product mass and hence, it has been observed that the moisture removing rate increases with increase in ginger samples mass and decreases significantly with the progression of drying days [27]. However, the moisture removing rate is also dependent on the ease of heat transfer. More the coefficient of convective heat transfer more will be the moisture removing rate and vice versa as illustrated in Figure 5. Forced 
convection drying system has been reported to be best suitable for faster drying as the value of coefficient of convective heat transfer associated with them is more than the natural convection drying [28]. From Figure 5, it has been observed that the values of convective heat transfer coefficient $\left(h_{c}\right)$ decreases with the progression of drying days (i.e. from first day of drying to the next day drying). This decrease in convective heat transfer coefficient value is due to continuous reduction in moisture removal rate from the first day to the next day of drying [29]. The values of convective heat transfer coefficient have been observed to be dependent on the mass of fresh ginger samples and decreases with increase in mass of the ginger samples. So, it has been reported that the drying kinetics of ginger is highly dependent on the mass taken into consideration.

\section{CONCLUSIONS}

The research reported in this paper includes the evaluation of convective heat transfer coefficient, moisture removing rate and collector efficiency for different mass of ginger samples under natural convection indirect solar drying mode. The experimental data were analysed by using Nusselt number expression with the help of linear regression method. The following observations and conclusions have been made:

i) The average values of convective heat transfer coefficient were reported to vary from 1.78 to $4.74 \mathrm{~W} / \mathrm{m}^{2 \circ} \mathrm{C}$ and 0.59 to $5.42 \mathrm{~W} / \mathrm{m}^{2 \circ} \mathrm{C}$ for 78 and 48 numbers of ginger samples respectively.

ii) Convective heat transfer coefficients for both mass of ginger samples decrease significantly with increase in the mass of ginger samples.

iii) The moisture removing rate on dry basis for each drying hour was evaluated and observed to be increased with increase in ginger samples mass and decreases significantly with the progression of drying days.

iv) The average collector efficiency during the drying process was also calculated and observed to vary from 14.97 to $16.14 \%$.

v) Modified page model was reported to be best suited for describing the drying behaviour of ginger for both mass of ginger samples.

vi) The experimental errors were evaluated in terms of percent uncertainty ranging from 29.19 to $46.25 \%$.

The experimental errors occurred during the drying process further reduced by using certain counter-measures such as sophisticated monitoring devices, design accuracy, and the selection of materials. The collector efficiency can be further improved by using high conductive absorber material, recirculation of drying air, supplement heat sources and the formation of obstacles inside the collector unit. The overall system effectiveness can also be enhanced by using phase change materials but it must be tested first in terms of chemical stability before being implemented in the existing system. Computer-based simulation tool is also an important method to study the design optimization and scalability of the system. The present research work could be considered for optimum design of a solar dryer for quality drying of various products.

\section{ACKNOWLEDGEMENTS}

One of the authors (S. K. Sansaniwal) would like to convey his appreciation to Guru Jambheshwar University of Science and Technology, Hisar, for providing laboratory facilities and technical assistance to carry out this research work successfully. 


\section{REFERENCES}

[1] Deshmukh AW, Varma MN, Yoo CK, Wasewar KL. Effect of ethyl oleate pretreatment on drying of ginger: characteristics and mathematical modelling. Journal of Chemistry. 2013;2013.

[2] Rahman H, Karuppaiyan R, Kishore K, Denzongpa R. Traditional practices of ginger cultivation in Northeast India. Indian Journal of Traditional Knowledge. 2009;8:23-8.

[3] Sundari ARU, Neelamegam P, Subramanian CV. Study and analysis of drying characteristics of ginger using solar drier with evacuated tube collectors. Research Journal of Pharmaceutical, Biological and Chemical Sciences. 2013;4:1258-67.

[4] Midilli A. Determination of pistachio drying behaviour and conditions in a solar drying system. International Journal of Energy Research. 2001;25:715-25.

[5] Tesfamariam DA, Kahsay MB, Kahsay MT, Hagos FY. Modeling and Experiment of Solar Crop Dryer for Rural Application. Journal of Chemical and Pharmaceutical Sciences. 2015:108-18.

[6] Gürlek G, Özbalta N, Güngör A. Solar tunnel drying characteristics and mathematical modelling of tomato. Journal of Thermal Science and Technology. 2009;29:15-23.

[7] Fudholi A, Ruslan MH, Othman MY, Zaharim A, Sopian K. Mathematical Modelling of Solar Drying of Thin Layer Ginger. Latest trends in Renewable Energy Environmental Informatics. 2013:273-8.

[8] Prasad J, Prasad A, Vijay V. Studies on the drying characteristics of Zingiber officinale under open sun and solar biomass (hybrid) drying. International Journal of Green Energy. 2006;3:79-89.

[9] Phoungchandang S, Nongsang S, Sanchai P. The development of ginger drying using tray drying, heat pump-dehumidified drying, and mixed-mode solar drying. Drying Technology. 2009;27:1123-31.

[10] Phoungchandang S, Saentaweesuk S. Effect of two stage, tray and heat pump assisted-dehumidified drying on drying characteristics and qualities of dried ginger. Food and Bioproducts Processing. 2011;89:429-37.

[11] Eze J, Agbo K. Comparative studies of sun and solar drying of peeled and unpeeled ginger. American Journal of Science and IndustryResearch. 2011;2:13643.

[12] Loha C, Das R, Choudhury B, Chatterjee PK. Evaluation of air drying characteristics of sliced ginger (Zingiber officinale) in a forced convective cabinet dryer and thermal conductivity measurement. Journal of Food Processing and Technology. 2012;2012.

[13] Jayashree E, Visvanathan R, Zachariah J. Quality of dry ginger (Zingiber officinale) by different drying methods. Journal of food Science and Technology. 2014;51:3190-8.

[14] Bhagat HA, Lawankar SM. Experimental study of PV powered forced circulation solar dryer with and without reflective mirror. Journal of Information, Knowledge and Research in Mechanical Engineering. 2012;1:88-93.

[15] Hoque M, Bala B, Hossain M, Uddin MB. Drying kinetics of ginger rhizome (Zingiber officinale). Bangladesh Journal of Agricultural Research. 2013;38:30119. 
[16] Deshmukh AW, Varma MN, Yoo CK, Wasewar KL. Investigation of solar drying of ginger (Zingiber officinale): Emprical modelling, drying characteristics, and quality study. Chinese Journal of Engineering. 2014;2014.

[17] Ranganna S. Handbook of analysis and quality control for fruit and vegetable products: Tata McGraw-Hill Education; 1986.

[18] Page GE. Factors influencing the maximum rates of air drying shelled corn in thin layers. M S Thesis, Purdue University, USA,1949.

[19] Henderson S, Pabis S. Grain drying theory I. Temperature effect on drying coefficient. Journal of Agricultural Engineering Research. 1961;6:169-74.

[20] Wang Z, Sun J, Liao X, Chen F, Zhao G, Wu J, et al. Mathematical modeling on hot air drying of thin layer apple pomace. Food Research International. 2007;40:39-46.

[21] Wang C, Singh R. A single layer drying equation for rough rice. ASAE paper; 1978.

[22] Kumar M. Experimental study on natural convection greenhouse drying of papad. Journal of Energy in Southern Africa. 2013;24:37-43.

[23] Kumar M. Forced convection greenhouse papad drying: an experimental study. Journal of Engineering, Science and Technology. 2013;8:177-89.

[24] Pangavhane DR, Sawhney R, Sarsavadia P. Design, development and performance testing of a new natural convection solar dryer. Energy. 2002;27:579-90.

[25] Nakra B, Chaudhry K. Instrumentation, measurement and analysis: Tata McGraw-Hill Education; 2003.

[26] Tiwari G. Solar energy technology advances: Nova Publishers; 2006.

[27] Kumar M. Effect of size on forced convection greenhouse drying of khoa. Journal of Mechanical Engineering and Sciences. 2014;7:1157-67.

[28] Kumar M, Khatak P, Sahdev RK, Prakash O. The effect of open sun and indoor forced convection on heat transfer coefficients for the drying of papad. Journal of Energy in Southern Africa. 2011;22:40-6.

[29] Kumar A, Tiwari G. Effect of shape and size on convective mass transfer coefficient during greenhouse drying (GHD) of jaggery. Journal of Food Engineering. 2006;73:121-34. 